\title{
Sawdust Addition Reduces the Productivity of Nitrogen-Enriched Mountain Grasslands
}

\author{
T. Spiegelberger, ${ }^{1,2,3,4}$ H. Müller-Schärer, ${ }^{2}$ D. Matthies, ${ }^{5}$ and U. Schaffner ${ }^{1}$
}

\begin{abstract}
Anthropogenic nutrient enrichment of mountain grasslands has boosted grasses and fast-growing unpalatable plants at the expense of slow-growing species, resulting in a significant loss in biodiversity. A potential tool to reduce nutrient availability and aboveground productivity without destroying the perennial vegetation is carbon $(\mathrm{C})$ addition. However, little is known about its suitability under severe climatic conditions. Here, we report the results of a 3-year field study assessing the effects of sawdust addition on soil nutrients, aboveground productivity, and vegetational composition of 10 grazed and ungrazed mountain grasslands. Of particular interest was the effect of $C$ addition on grasses and on the tall unpalatable weed Veratrum album. After 3 years, soil pH, ammonium, and plant-available phosphorus were not altered by sawdust application, and nitrate concentrations were marginally higher in treatment
\end{abstract}

plots. However, the biomass of grasses and forbs (without $V$. album) was $20-25 \%$ lower in sawdust-amended plots, whereas the biomass of $V$. album was marginally higher. Sawdust addition reduced the cover of grasses but did not affect evenness, vegetation diversity, or plant species richness, although species richness generally increased with decreasing biomass at our sites. Our results suggest that sawdust addition is a potent tool to reduce within a relatively short time the aboveground productivity and grass cover in both grazed and ungrazed mountain grasslands as long as they are not dominated by tall unpalatable weeds. The technique has the advantage that it preserves the topsoil and the perennial soil seed bank.

Key words: carbon addition, competitive interactions, European Alps, multisite field experiment, seminatural grasslands, soil nutrient availability, restoration.

\section{Introduction}

Nitrogen $(\mathrm{N})$ is a limiting resource for plant growth in many temperate terrestrial ecosystems (Vitousek et al. 1997). Increasing the $\mathrm{N}$ supply in such ecosystems not only increases primary production but also alters species dominance and composition (Gough et al. 2000). Theoretical and experimental works suggest that above a certain level of primary productivity, species diversity declines with $\mathrm{N}$ supply (Suding et al. 2005; Silvertown et al. 2006), making the increased deposition of anthropogenically derived $\mathrm{N}$ one of the most important causes of biodiversity loss worldwide (Sala et al. 2000). Given that human activity has doubled globally the amount of $\mathrm{N}$ available in the past 50 years and that critical loads to maintain the plant diversity of grasslands are exceeded in many parts of North America and Europe, methods are needed to counter the

\footnotetext{
${ }^{1}$ CABI Europe-Switzerland, Rue des Grillons 1, CH-2800 Delémont, Switzerland

${ }^{2}$ Department of Biology, University of Fribourg, Unit Ecology and Evolution, Chemin du Musée 1, CH-1700 Fribourg, Switzerland

${ }^{3}$ Present address: Cemagref de Grenoble, Research Unit Mountain Ecosys-

tems, 2 rue de la Papeterie, F-38402 Saint-Martin-d'Hères, France

${ }^{4}$ Address correspondence to T. Spiegelberger, email thomas.spiegelberger@ cemagref.fr

${ }^{5}$ Department of Biology, University of Marburg, Karl-von-Frisch-Strasse 8,

D-35032 Marburg, Germany
}

negative effects of nutrient enrichment on N-limited ecosystems and especially to mitigate the loss of species diversity.

Plant species richness of mountain grasslands is still high compared with many grasslands in lowland areas (MacDonald et al. 2000). However, because N mineralization rates and $\mathrm{N}$ uptake by plants are low in mountain grasslands (Körner 2003) and because their vegetation consists mainly of plants adapted to the efficient use of $\mathrm{N}$ (Kammer \& Möhl 2002), even small amounts of additional inorganic $\mathrm{N}$ may have a substantial impact on the species richness and composition of mountain grasslands. Several studies have found that fertilization of mountain grasslands increases the dominance of grasses, which in turn suppress species adapted to low $\mathrm{N}$ conditions and reduces species richness (Oksanen 1990; Theodose \& Bowman 1997; Spiegelberger et al. 2006b). Another group of plant species that has been found to decrease species richness on mountain grasslands are fast-growing unpalatable forbs, such as White hellebore (Veratrum album L.), Broad-leaved dock (Rumex obtusifolius L.), or Wooly thistle (Cirsium eriophorum L.; Kleijn \& Müller-Schärer 2006; Spiegelberger et al. 2006b). High densities of the toxic $V$. album increase the likelihood that mountain grasslands are abandoned (in particular in the European Alps; N. Doutaz 2003, Institut agricole de Grangeneuve, Fribourg, Switzerland, personal communication). Although $R$. obtusifolius has been shown to profit from 
fertilization (Zaller 2004), little is known about the direct effect of soil $\mathrm{N}$ availability on $V$. album and other unpalatable species of mountain grasslands. One would expect, however, that fertilization of mountain grasslands would indirectly promote unpalatable plants because fertilization usually entails increased cattle stocking rates and hence increased grazing pressure.

Increased $\mathrm{N}$ levels in mountain grasslands have mainly two causes: anthropogenic fertilizer application and aerial $\mathrm{N}$ deposition. Although $\mathrm{N}$ input through fertilization could be stopped within a short time through changes in land management, aerial $\mathrm{N}$ deposition is likely to increase or at least continue at similar levels for several decades (Galloway \& Cowling 2002). Efforts to restore formerly species-rich mountain grasslands that are $\mathrm{N}$ enriched and dominated by grasses and unpalatable forbs should therefore aim to reduce plant-available N. Restoration techniques currently applied in lowland areas to decrease soil nutrient availability involve topsoil removal or maximizing the removal of aboveground biomass, but both techniques are not suitable for mountain grasslands.

An alternative technique to lower plant-available $\mathrm{N}$ levels is the addition of a labile carbon (C) source to the soil. $\mathrm{C}$ addition to the soil has been shown to stimulate soil microbial activity, resulting in an increased immobilization of inorganic $\mathrm{N}$ (Schmidt et al. 1997b; Blumenthal et al. 2003). In the absence of confounding factors such as interspecific competition, $\mathrm{C}$ addition has been shown to negatively affect the growth of most if not all plant species, but the extent of reduction varies significantly among species. Although annual species and perennial grasses show a significant decrease in aboveground biomass, the response of legumes to $\mathrm{C}$ addition appears to be less pronounced (Eschen et al. 2006). Despite its general negative effect on plant growth, $\mathrm{C}$ addition under field conditions may increase the cover of slow-growing species, probably due to a release from competition for light (Blumenthal et al. 2003). C addition has successfully been used to selectively influence the competitive interactions among native plant species during early succession (Török et al. 2000; Eschen et al. 2007) and between invasive and native species (Alpert \& Maron 2000; Blumenthal et al. 2003). However, it has rarely been tested as a tool to alter the community composition of native perennial vegetation (Michelsen et al. 1999; Prober et al. 2005).

In nutrient-rich lowland habitats, where plant growth is thought to be primarily limited by the availability of inorganic soil N (Schimel \& Bennett 2004), C amendments have been shown to immobilize inorganic soil $\mathrm{N}$ and to limit the growth of plants (Reever Morghan \& Seastedt 1999; Corbin \& D'Antonio 2004). In contrast, plants of arctic and alpine habitats can acquire up to $35 \%$ of their total $\mathrm{N}$ requirement from organic sources (Nordin et al. 2004), rendering them less dependent of inorganic $\mathrm{N}$ than plants growing in habitats with milder climatic conditions. Arbuscular mycorrhizal fungi (AMF) are likely to act as a support system for plants growing under harsh climatic conditions by facilitating the decomposition and acquisition of N from organic sources (Hodge et al. 2001; Schimel \& Bennett 2004). Because plants from cold climatic ecosystems appear to be less dependent of inorganic $\mathrm{N}$, it is unclear whether $\mathrm{C}$ addition in mountain plant communities is a suitable management tool to reduce aboveground productivity or to manipulate vegetation composition.

Here, we report the results of a 3-year field study to quantify the effects of $\mathrm{C}$ addition applied as sawdust on soil inorganic nutrients, aboveground productivity, and vegetation composition of mountain grasslands. In particular, we were interested in assessing the response of grasses and of $V$. album, which was chosen as a model species for fast-growing, unpalatable pasture weeds. We hypothesized that sawdust addition would overproportionally reduce the growth of grasses. No specific predictions could be made in terms of the effect of sawdust addition on $V$. album because direct effects of soil $\mathrm{N}$ availability on $V$. album cover or biomass have not been studied. In general, we predicted that in the long term, sawdust addition should promote the competitive ability of slow-growing species characteristic of mountain grasslands and ultimately lead to increased species richness.

\section{Methods}

\section{Study Sites and Treatments}

In spring 2002, we selected 10 sites below the tree line in two mountain ranges (Swiss Jura and Alps; cf Table 1). All sites were heavily infested by Veratrum album. Veratrum album is a long-lived unpalatable plant common in mountain grasslands, which has attained pest status in underexploited or abandoned pastures in France, Switzerland, Italy, Austria, and Slovenia (Food and Agriculture Organization of the United Nations, unpublished report). Large herbivores do not browse on $V$. album due to the high alkaloid concentration (cf Schaffner et al. 2001 and Kleijn \& Müller-Schärer 2006, for a more detailed description of $V$. album and its ecology).

At each site, we set up one plot of $6 \times 3 \mathrm{~m}$ each in a grazed and an ungrazed grassland. Grazed grasslands were used as pastures for dairy cattle or young heifers. Ungrazed grasslands had been formerly used as pastures and were abandoned 1-30 years before the beginning of the experiment (cf Table 1). In a few cases, farmers indicated that the cattle might be driven across the ungrazed grasslands; therefore, these plots were fenced with barbed wire at the start of the experiment. The maximum distance between two paired plots was $1 \mathrm{~km}$. All study sites were dominated by grasses with legumes representing approximately $10 \%$ of the cover of all forbs and $5 \%$ of the biomass of all forbs.

Each plot was divided into two $3 \times 3-$ m subplots. From 2002 to 2004, air-dried sawdust was spread out by hand to the vegetation of one subplot during three subsequent months at a rate of $0.5 \mathrm{~kg} / \mathrm{m}^{2}$ per application (resulting in a total of $1.5 \cdot \mathrm{kg} \cdot \mathrm{m}^{2} \cdot \mathrm{yr}^{-1}$ ), starting immediately after 
Table 1. Description of the study sites.

\begin{tabular}{|c|c|c|c|c|c|c|c|c|}
\hline Site & Region & Latitude & Longitude & Elevation $(m)$ & $\begin{array}{c}\text { Mean Annual } \\
\text { Precipitation }(\mathrm{mm})\end{array}$ & $\begin{array}{c}\text { Mean Annual } \\
\text { Temperature }\left({ }^{\circ} \mathrm{C}\right)\end{array}$ & $\begin{array}{l}\text { Days with } \\
\text { Frost }\end{array}$ & $\begin{array}{l}\text { Abandoned } \\
\text { since }\end{array}$ \\
\hline Col des Mosses & Alps, $\mathrm{CH}$ & $46^{\circ} 25^{\prime} \mathrm{N}$ & $7^{\circ} 05^{\prime} \mathrm{E}$ & 1,500 & 1,366 & 6.1 & 140 & $<1970$ \\
\hline Grenchenberg & Jura, CH & $47^{\circ} 13^{\prime} \mathrm{N}$ & $7^{\circ} 23^{\prime} \mathrm{E}$ & 1,370 & 1,155 & 3.2 & 160 & 2002 \\
\hline La Meuser & Jura, CH & $47^{\circ} 08^{\prime} \mathrm{N}$ & $7^{\circ} 02^{\prime} \mathrm{E}$ & 1,400 & 1,155 & 3.2 & 160 & 2002 \\
\hline La Petite Ronde & Jura, CH & $46^{\circ} 55^{\prime} \mathrm{N}$ & $6^{\circ} 27^{\prime} \mathrm{E}$ & 1,140 & 1,274 & 5.3 & 133 & 1985 \\
\hline Mungbach & Alps, CH & $46^{\circ} 34^{\prime} \mathrm{N}$ & $7^{\circ} 15^{\prime} \mathrm{E}$ & 1,380 & 1,249 & 6.1 & 123 & 2002 \\
\hline Tremont & Alps, $\mathrm{CH}$ & $46^{\circ} 29^{\prime} \mathrm{N}$ & $7^{\circ} 05^{\prime} \mathrm{E}$ & 1,480 & 982 & 2.0 & 183 & 1998 \\
\hline Vieille Mole & Jura, CH & $47^{\circ} 06^{\prime} \mathrm{N}$ & $6^{\circ} 59^{\prime} \mathrm{E}$ & 1,090 & 1,406 & 5.8 & 151 & 2002 \\
\hline
\end{tabular}

Climate data were obtained from the nearest permanent weather station (available at http://www.meteoswiss.ch and http://www.meteo.fr). CH, Switzerland; F, France; NA, data not available.

snowmelt, except for the first year, when applications started in June. After each application, sawdust attached to plants was cleaned through carefully shaking the vegetation. Sawdust on the ground represented a fine layer of circa $2 \mathrm{~mm}$ hardly exceeding the cover of decaying plant debris. Application quantity and timing were chosen similar to those in previous studies (Alpert \& Maron 2000; Corbin \& D'Antonio 2004). Sawdust was obtained from a local sawmill and consisted of beech wood only. The other subplot was used as control.

\section{Soil, Biomass, and Vegetation Sampling}

Twelve soil samples $(\varnothing 2.5 \mathrm{~cm}$, depth $10 \mathrm{~cm})$ were taken in the outer $0.5 \mathrm{~m}$ of each subplot in autumn 2004 and pooled per subplot. They were transferred to a deep freezer $\left(-18^{\circ} \mathrm{C}\right)$ within a few hours after sampling and kept frozen until further processing. $\mathrm{NH}_{4}^{+}$and $\mathrm{NO}_{3}^{-}$concentrations (expressed as $\mathrm{mg} \mathrm{N} / \mathrm{kg}$ soil) were measured with a colorimeter (Flow analyzer, Skalar San Plus, Breda, The Netherlands) after solving $50 \mathrm{~g}$ soil in $250 \mathrm{~mL}$ of $1 \mathrm{M}$ $\mathrm{KCl}$ and orthophosphate with the Olsen method (Olsen et al. 1954). Soil $\mathrm{pH}$ was measured after shaking $1 \mathrm{~g}$ soil in $5 \mathrm{~mL}$ distilled water for 15 minutes. All soil analyses were carried out by SADEF, Aspach, France.

Aboveground biomass was harvested in autumn 2004 at least 6 weeks after the cattle had left the pasture to allow for regrowth of the vegetation, and in spring 2005, before cattle started to graze. Aboveground biomass of all forbs (except for $V$. album) and that of grasses including dead standing biomass was clipped $1 \mathrm{~cm}$ aboveground in two $0.2 \times 0.5-\mathrm{m}$ rectangles $\left(0.2 \mathrm{~m}^{2}\right.$ in total $)$ in the outer $0.5 \mathrm{~m}$ of each subplot and pooled per subplot to obtain the biomass of the two functional groups. These two functional groups together are subsequently called "matrix vegetation." The biomass of the matrix vegetation was dried for 2 days at $80^{\circ} \mathrm{C}$, weighed, and in spring 2005 , divided into grass and forb biomass. In autumn 2004, when the aboveground parts of $V$. album had started to die-back, the number of shoots of $V$. album of each subplot was counted in the central $2 \times 2-\mathrm{m}$ square and the plants harvested aboveground dried for 2 days at $80^{\circ} \mathrm{C}$ and was weighed. Biomass per shoot was calculated as aboveground $V$. album biomass per plot divided by the number of shoots per plot. Three plots had to be excluded from further analysis because farmers had already cut the shoots of $V$. album. For comparisons with the matrix vegetation, the biomass of $V$. album was corrected for the larger sampling area used. To obtain the total biomass per plot, we summed up the corrected biomass of $V$. album and the biomass of the matrix vegetation in autumn 2004.

In each subplot, the vegetation of the central $2 \times 2-\mathrm{m}$ square was censused in summer 2002 and spring 2005. The foliar cover of each plant species, bare ground, and rocks were visually estimated to the nearest percent. Species with a cover of less than $1 \%$ were assigned a cover value of $0.5 \%$. The cover of all forbs (except for that of $V$. album) and that of grasses was pooled to obtain the total cover of the matrix vegetation. Cover data from summer 2002 were used to assess possible initial differences in vegetation cover among treatments. The results indicated that at the beginning of the experiment, total vegetation cover, cover of $V$. album, cover of grasses, and cover of forbs did not consistently differ between the control plots and those plots that subsequently received sawdust addition across all experimental sites (analyses of variance as described below; all $p>0.1$ ), nor did vegetation composition differ between plots that had been abandoned five and more years prior to the experiment and plots that had been abandoned more recently (canonical correspondence analysis [CCA] as described below; all $p>0.8$ ). The study sites can be considered as nitrogen rich as their average soil inorganic $\mathrm{N}$ concentration (nitrate and ammonium; see Results section below) was considerably higher than that found in subalpine grasslands of the French Alps (circa 22-30 mg/kg for unterraced grasslands at 1650-2000 above sea level; Robson et al. 2007).

\section{Statistical Analysis}

Cover data were used to calculate the Shannon-Wiener index of diversity $\left(H=-\sum p_{i} \ln p_{i}\right.$, where $p_{i}$ is the 
relative abundance of species $i)$ and evenness $\left(H / H_{\max }=\right.$ $H / \log S$, where $S$ is the species richness). To assess the relationship between total aboveground biomass and plant species richness, a linear model using only the control plots $(n=17)$ was calculated. Univariate data were analyzed by general linear effect models with grazing and $\mathrm{C}$ treatment as fixed factors and site and plot as spatial random effects. The effects of site and grazing were tested against the variation among plots, those of $\mathrm{C}$ treatment and its interaction with grazing against the variation among the subplots. Vegetation data were log transformed prior to analysis. Because this study was carried out under field conditions with considerable natural variation among the experimental plots, marginally significant results $(0.05<p<0.1)$ are mentioned as well. Differences in vegetational composition were analyzed by CCA using CANOCO 4.02 (Ter Braak \& Šmilauer 1999). The significance of the treatment effects was tested using the randomization test available in CANOCO. All other analyses were carried out with the $R$ statistical language 2.4.0 (http://cran.r-project.org/).

\section{Results}

\section{Soil Variables}

Sawdust application neither influenced soil pH $(5.8 \pm 0.15$ for control vs. $5.9 \pm 0.14$ for sawdust treatment; $p=0.150$ ) nor the concentrations of $\mathrm{NH}_{4}^{+}(48.8 \pm 6.52$ vs. $43.5 \pm 4.65$ $\mathrm{mg} \mathrm{N} / \mathrm{kg}$ soil; $p=0.310)$ or orthophosphate $(11.4 \pm 1.56$ vs. $11.8 \pm 1.46 \mathrm{mg} \mathrm{P} / \mathrm{kg}$ soil; $p=0.882$ ), whereas $\mathrm{NO}_{3}^{-}$ concentrations were marginally higher in treatment plots
$(2.7 \pm 1.01 \mathrm{mg}$ vs. $1.4 \pm 0.35 \mathrm{~N} / \mathrm{kg}$ soil; $p=0.094)$. No significant differences were found between grazed and ungrazed plots in terms of concentrations of $\mathrm{NH}_{4}^{+}(41.9 \pm$ 5.31 for grazed vs. $55.6 \pm 11.86 \mathrm{mg} \mathrm{N} / \mathrm{kg}$ soil for ungrazed plots; $p=0.265)$ and orthophosphate (12.5 \pm 2.04 vs. 10.3 $\pm 2.40 \mathrm{mg} \mathrm{P} / \mathrm{kg}$ soil; $p=0.289)$; however, soil $\mathrm{pH}(5.7 \pm$ 0.16 vs. $6.0 \pm 0.24 ; p=0.060)$ and $\mathrm{NO}_{3}^{-}(0.8 \pm 0.23$ vs. 2.0 $\pm 0.61 \mathrm{mg} \mathrm{N} / \mathrm{kg}$ soil; $p=0.070$ ) were marginally lower at grazed sites.

\section{Aboveground Biomass}

In autumn 2004, total aboveground biomass was marginally lower $(14 \%)$ and aboveground biomass of the matrix vegetation was significantly lower $(20 \%)$ in the sawdustamended plots than in the control plots (Tables $2 \& 3 a$ ). Similarly, aboveground biomass of the matrix vegetation in spring 2005 was significantly and about $25 \%$ lower in sawdust-amended plots than in control plots. The biomass of grasses and that of forbs was significantly lower and was affected to a similar extent (Tables $2 \& 3 a$ ). In contrast, the biomass of Veratrum album was marginally higher (Tables $2 \& 3 a$ ), but number of shoots (control: $21 \pm 3.1$, sawdust: $27 \pm 4.3 ; p>0.15)$ and biomass per shoot of $V$. album (control: $7.5 \pm 0.92 \mathrm{~g}$, sawdust: $7.6 \pm 0.91 \mathrm{~g} ; p>0.9$ ) were not influenced by $\mathrm{C}$ addition.

In autumn 2004, grazed plots had significantly less total and less matrix biomass (circa 30\%) compared to ungrazed plots (Tables 2 \& 3a). In spring 2005, grazed plots had significantly less grass biomass $(35 \%)$ and less forb biomass $(45 \%)$ than ungrazed plots (Tables $2 \& 3 a)$, probably because ungrazed plots contained more standing

Table 2. Means $\pm 1 \mathrm{SE}$ for the effect of grazing and of $\mathrm{C}$ addition in the form of sawdust during three vegetation periods on the overall biomass (g) and the biomass of various components of the vegetation per $0.2 \mathrm{~m}^{2}$ in autumn 2004 and in spring 2005 and the mean cover (\%) and number of species per plot $\left(4 \mathrm{~m}^{2}\right)$ in spring 2005 .

\begin{tabular}{|c|c|c|c|c|c|c|c|c|c|c|}
\hline & & \multicolumn{5}{|c|}{ Biomass in Autumn 2004 (g) } & \multicolumn{4}{|c|}{ Biomass in Spring 2005 (g) } \\
\hline & & \multicolumn{3}{|c|}{ Grazed } & \multicolumn{2}{|c|}{ Ungrazed } & \multicolumn{2}{|c|}{ Grazed } & \multicolumn{2}{|c|}{ Ungrazed } \\
\hline Total & & $50 \pm$ & & $40 \pm 4.5$ & $68 \pm 4.4$ & $61 \pm 4.5$ & - & - & - & - \\
\hline Matrix & & $41 \pm$ & & $31 \pm 4.6$ & $59 \pm 4.0$ & $49 \pm 4.7$ & $38 \pm 5.5$ & $24 \pm 3.4$ & $55 \pm 5.6$ & $47 \pm 4.6$ \\
\hline \multirow[t]{4}{*}{ Veratrum al } & $u m$ & $6.8 \pm$ & & $7.4 \pm 1.0$ & $6.3 \pm 1.4$ & $9.0 \pm 1.6$ & - & - & - & - \\
\hline & \multicolumn{6}{|c|}{ Cover in Spring 2005 (\%) } & \multicolumn{4}{|c|}{ Species Number in Spring 2005} \\
\hline & \multicolumn{4}{|c|}{ Grazed } & \multicolumn{2}{|c|}{ Ungrazed } & \multicolumn{2}{|c|}{ Grazed } & \multicolumn{2}{|c|}{ Ungrazed } \\
\hline & \multicolumn{2}{|c|}{ Control } & \multicolumn{2}{|c|}{$C$ Addition } & Control & $C$ Addition & Control & C Addition & Control & C Addition \\
\hline Forbs & & \pm 2.9 & & $36 \pm 3.3$ & $42 \pm 4.6$ & $41 \pm 4.5$ & $19.9 \pm 1.1$ & $19.2 \pm 1.3$ & $17.9 \pm 1.9$ & $17.9 \pm 1.7$ \\
\hline V. album & & \pm 2.8 & & $15 \pm 3.7$ & $12 \pm 3.1$ & $11 \pm 1.9$ & - & - & - & - \\
\hline
\end{tabular}


Table 3. Analysis of variance model of the effects of site, grazing, plot, $\mathrm{C}$ addition, and the interaction of grazing and $\mathrm{C}$ addition on (a) biomass in autumn 2004 and spring 2005 and (b) plant cover and species richness in spring 2005.

\begin{tabular}{|c|c|c|c|c|c|c|c|c|c|c|c|c|c|c|}
\hline \multirow[t]{2}{*}{ (a) } & \multicolumn{8}{|c|}{ Biomass Autumn 2004} & \multicolumn{6}{|c|}{ Biomass Spring 2005} \\
\hline & \multicolumn{3}{|c|}{ Total } & \multicolumn{2}{|c|}{ Matrix } & \multicolumn{3}{|c|}{ Veratrum album } & \multicolumn{2}{|c|}{ Matrix } & \multicolumn{2}{|c|}{ Grasses } & \multicolumn{2}{|c|}{ Forbs } \\
\hline Site & 9 & 3.9 & 0.044 & 1.5 & 0.266 & 1. & & & 1.1 & 0.430 & 1.2 & 0.410 & 3.0 & 0.057 \\
\hline Grazing (G) & 1 & 12.4 & 0.010 & 10.5 & 0.010 & 0. & & & 15.3 & 0.004 & 6.4 & 0.032 & 22.1 & 0.001 \\
\hline Plot & 9 & 1.3 & 0.336 & 2.9 & 0.027 & 3.5 & & & 1.3 & 0.294 & 1.5 & 0.212 & 1.6 & 0.199 \\
\hline \multirow[t]{3}{*}{ (b) } & \multicolumn{11}{|c|}{ Cover } & \multicolumn{3}{|c|}{ Species Richness } \\
\hline & \multicolumn{3}{|c|}{ Total } & \multicolumn{2}{|c|}{ Matrix } & \multicolumn{2}{|c|}{ Grasses } & \multicolumn{2}{|c|}{ Forbs } & \multicolumn{2}{|c|}{ V. album } & & & \\
\hline & $d f$ & $F$ & $p$ & $F$ & $p$ & $F$ & $p$ & $F$ & $p$ & $F$ & $p$ & & & $p$ \\
\hline $\mathrm{C}$ addition $(\mathrm{C})$ & 1 & 3.6 & 0.074 & 6.4 & 0.021 & 6.8 & 0.018 & 1.1 & 0.301 & 2.8 & 0.114 & & & 0.759 \\
\hline $\mathrm{G} \times \mathrm{C}$ & 1 & 1.3 & 0.263 & 0.0 & 0.871 & 0.6 & 0.448 & 0.7 & 0.418 & 0.9 & 0.349 & & & 0.571 \\
\hline
\end{tabular}

The effects of site and grazing were tested against the residual variation among plots, all other effects against the residual. Significant $p$ values $(p<0.05)$ are in boldface and marginally significant $p$ values $(0.05<p<0.1)$ are in italics.

dead biomass than grazed plots. There was no significant interaction between the effects of sawdust treatment and grazing, neither in autumn 2004 nor in spring 2005 (Table 3a).

Species richness per plot in spring 2005 decreased significantly with total aboveground biomass in autumn 2004 (Fig. 1).

\section{Vegetation Cover and Composition in 2005}

In spring 2005, total vegetation cover was marginally lower and the cover of the matrix vegetation significantly lower in the sawdust-amended plots (Tables 2 \& $3 b)$. The lower cover of the matrix vegetation was mainly due to a significant reduction in the cover of grasses (by about $5 \%$ ) in sawdust-amended plots, whereas neither the cover of forbs nor of $V$. album was affected (see Appendix S1 for individual cover values of selected species). Abandonment of grazing significantly reduced the cover of grasses (Tables $2 \& 3 \mathrm{~b}$ ) and led to a different vegetation composition (CCA, $\left.F_{[1,9]}=1.5 ; p=0.004\right)$ but did not interact with the sawdust treatment $(p>0.2)$. The decrease in grass cover by sawdust addition did not change the overall vegetational composition in spring $2005\left(\mathrm{CCA}, F_{[1,18]}=0.9 ; p>0.8\right)$ and did not increase the proportion of bare ground $\left(F_{[1,18]}=1.2 ; p>0.2\right)$. Moreover, the sawdust treatment did not change species richness per plot $\left(F_{[1,18]}=0.1 ; p>0.7 ;\right.$ Table 2$)$, Shannon-Wiener diversity index (C treatment: $2.90 \pm$ 0.066 vs. control: $2.88 \pm 0.067$; grazed: $2.94 \pm 0.054$ vs. ungrazed: $2.84 \pm 0.076 ; p>0.1$ ) or evenness ( $\mathrm{C}$ treatment:
$0.863 \pm 0.009$ vs. control: $0.858 \pm 0.012$; grazed: $0.861 \pm$ 0.011 vs. ungrazed: $0.861 \pm 0.011 ; p>0.1$ ).

\section{Discussion}

This study provides some first experimental evidence that the aboveground productivity of mountain grasslands can

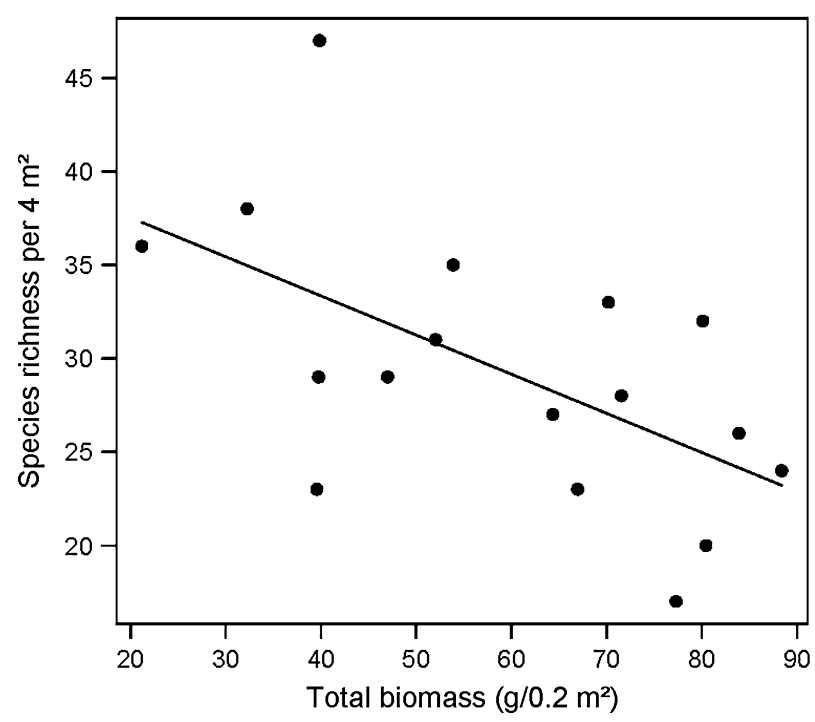

Figure 1. The relationship between species richness per $4 \mathrm{~m}^{2}$ in spring 2005 and total aboveground biomass per $0.2 \mathrm{~m}^{2}$ in autumn 2004 for control plots of the experimental study $\left(r^{2}=0.33, p=0.014\right.$; $n=17)$. 
be reduced by $\mathrm{C}$ addition within a relative short period of time and without disturbing the soil or the perennial vegetation. After 3 years of consecutive application of sawdust, the aboveground biomass of the matrix vegetation (all plants except Veratrum album) was significantly reduced by $\mathrm{C}$ addition. Similarly, in a complementary greenhouse study, the productivity of two phytometer plants (Festuca rubra and Poa alpina) grown in soil collected from the $\mathrm{C}$-amended field plots was significantly lower compared to plants grown in soil from control plots (Spiegelberger 2006); these results indicate that the biomass reduction of the matrix vegetation in the field experiment was due to altered soil nutrient cycling and not due to shading of the soil surface or the vegetation by the sawdust. We therefore propose that sawdust addition is a promising tool to reduce aboveground productivity of $\mathrm{N}$-enriched mountain grasslands. Unlike Michelsen et al. (1999), we applied a less easily degradable and cheaper form of $\mathrm{C}$ (sawdust) and assessed the effect of $\mathrm{C}$ addition at the community level. Furthermore, in contrast to the study of McLendon and Redente (1992), we applied sawdust directly on the perennial vegetation. Because our multisite study covered a range of different soil and climatic conditions, we are confident in our finding that sawdust addition alone can reduce the aboveground productivity of a variety of grazed and ungrazed mountain grasslands as long as the vegetation is not dominated by tall unpalatable plants.

\section{Lack of Detectable Changes in Soil Variables After Sawdust Addition}

Although 3 years of sawdust addition significantly reduced the aboveground productivity of the matrix vegetation, soil inorganic $\mathrm{N}$ levels did not vary between $\mathrm{C}$-amended plots and control plots. Our soil samples were taken in late autumn (together with the aboveground biomass), when inorganic $\mathrm{N}$ concentrations were low. Nutrient uptake by plants in cold-climate grasslands is highest immediately after snowmelt when nutrients are leached from the microbial biomass (Schimel \& Mikan 2005). Possibly, inorganic $\mathrm{N}$ decreased after sawdust addition early in the season, but these changes did not persist over the whole growing season (Prober et al. 2005; Eschen et al. 2007). An alternative explanation is that in cold- or high-elevation ecosystems, in contrast to many other ecosystems, a high proportion of nutrients is fixed in the soil organic matter. Nutrients are only slowly released because of environmental constraints on decomposition and high nutrient immobilization by soil microorganisms. In a nutrient addition experiment on an alpine grassland, Bowman et al. (2006) found that changes in vegetation composition preceded detectable changes in traditionally measured inorganic $\mathrm{N}$ pools in the soil. Moreover, in arctic and alpine ecosystems with low amounts of inorganic $\mathrm{N}$, organic $\mathrm{N}$ (which we did not measure) is considered to be a significant $\mathrm{N}$ source for many herbaceous plants, which form a symbiotic relationship with AMF (Schimel \& Bennett 2004). In a greenhouse experiment, reduction of AMF levels through fungicide application resulted in a $20 \%$ decrease of the productivity of phytometer plants growing in sawdust-amended soil from our study sites (Spiegelberger 2006), indicating that AMF are an important support system that may, to some extent, compensate for lower nutrient availability.

\section{Response of Plant Functional Groups}

The reduction in the aboveground biomass of the matrix vegetation in response to sawdust addition was paralleled by a change in the cover of functional groups. Although the biomass of grasses and forbs was affected to a similar degree, the cover of grasses was more strongly reduced by sawdust addition than that of forbs. Previous field studies (Michelsen et al. 1999; Eschen et al. 2007) and greenhouse studies (Schmidt et al. 1997a; Eschen et al. 2006) have also found that the cover or biomass of grasses was significantly reduced by soil $\mathrm{C}$ addition, whereas that of forbs was not affected or even increased. A possible explanation for the stronger response of grasses to $\mathrm{C}$ addition is that grasses react rapidly to changes in nutrient availability by an increased allocation of resources to belowground growth (Schmidt et al. 1997a; Eschen et al. 2006).

In contrast, the biomass of the unpalatable weed $V$. album was marginally higher on C-amended plots than on control plots. $\mathrm{C}$ addition has been used repeatedly to restore nutrient-enriched lowland grasslands invaded by exotic weeds. In most of these studies, the cover or productivity of the exotic weeds was successfully reduced (e.g., Alpert \& Maron 2000; Blumenthal et al. 2003; Prober et al. 2005). The apparent lack of response of $V$. album to sawdust addition may be due to its large belowground storage organ that may act as a buffer against reduced nutrient availability. Approximately $60 \%$ of the $\mathrm{N}$ allocated to shoot growth of $V$. album at peak biomass originates from stored reserves (Kleijn et al. 2005) indicating a significant capacity of $V$. album to store $\mathrm{N}$ in belowground organs. As a consequence, $V$. album is likely to respond only slowly, if at all, to changes in soil nutrient supply. Therefore, decreasing the aboveground biomass of $V$. album and other weeds with large underground storage organs may not be feasible with $\mathrm{C}$ addition alone. Early cutting and prevention of seed production of these unpalatable weeds may be a more efficient method for their control (Hesse et al. 2006).

\section{Plant Species Richness, Grass Cover, and Sawdust Addition}

Studies in subalpine (Antonsen \& Olsson 2005) and alpine grasslands (Jaeger et al. 1999) indicate that graminoids profit most from elevated nutrient availability and increase both their productivity and cover in response to fertilization. Moreover, in a comparative study in European mountain grasslands, Spiegelberger et al. (2006b) 
found that plant species richness peaked at a grass cover of about $40 \%$, whereas species richness was lowest when grass cover was $50 \%$ or more. In the current experiment, 3 years of sawdust application reduced the grass cover from 50 to $45 \%$. Hence, by reducing the aboveground productivity and cover of grasses, $\mathrm{C}$ addition creates conditions that should facilitate the survival and/or recovery of slow-growing plant species that are not able to compete with fast-growing species in nutrient-enriched mountain grasslands. However, neither species richness nor evenness of the vegetation did change over the 3-year study period, which may be due to the fact that most high-altitudinal plants are long lived and have developed mechanisms that allow them to persist even under strong nutrient limitation (Körner 2003). Nevertheless, sawdust addition over an extended period of time might increase species richness or evenness by releasing slow-growing plant species from aboveground competition through an overproportional reduction of the cover of grasses (Blumenthal et al. 2003).

\section{Grazing Versus Sawdust Addition}

Grazing is often recommended as an alternative and lowcost technique to maintain the species richness of mountain grasslands, as it increases spatial heterogeneity and may in consequence result in higher species richness (Austrheim \& Eriksson 2001). However, the effects of grazing on already nutrient-enriched grasslands are less clear. In our study, grazing increased the cover of grasses by circa $10 \%$, whereas sawdust addition reduced the cover of grasses by about $5 \%$. Carbon addition, grazing, and cutting of large weeds might be combined to achieve the best results.

\section{Conclusions}

Our experiment provides first evidence that sawdust addition is a promising method to reduce or mitigate the negative effects of anthropogenic nutrient enrichment on mountain grasslands. The relatively quick response of grasses to $\mathrm{C}$ addition is remarkable because mountain ecosystems are characterized by low nutrient turnover rates and a slow recovery from changes in nutrient availability (Spiegelberger et al. 2006a). Three years of sawdust addition reduced the aboveground biomass of the matrix vegetation but did not (yet) increase species richness, although species richness generally increased with decreasing biomass at our sites. The vegetation of mountain grasslands consists almost exclusively of long-lived plant species and increases in plant species richness may therefore require more time. Further research is needed (1) to study the long-term effects of sawdust amendment on the species richness of nutrient-enriched mountain grasslands and (2) to assess the sustainability of these measures under various land-use scenarios.

\section{Implications for Practice}

- A few years of $\mathrm{C}$ addition in form of sawdust to mountain grassland soil can lead to a reduction in aboveground productivity without mechanically disturbing the perennial vegetation of mountain grassland.

- This method appears to be particularly suitable to reduce the aboveground biomass and cover of grasses. In contrast, large unpalatable weeds with large underground storage organs may not be negatively affected and may require mechanical removal.

- The species richness of the vegetation did not change in response to sawdust addition over the course of the 3-year study period. Because mountain grasslands consist almost exclusively of long-lived plant species, a positive effect on species richness might require a longer period of sawdust addition.

\section{Acknowledgments}

This work was funded by the Swiss Priority Program (National Research Programme 48) "Landscapes and Habitats of the Alps," a research project of the Swiss National Science Foundation (grant 4048-064424 to Heinz Müller-Schärer and Urs Schaffner). We are grateful to all landowners who allowed us to establish experimental plots in their pastures. We thank S. Windhager and a number of anonymous reviewers whose comments substantially improved this article.

\section{LITERATURE CITED}

Alpert, P., and J. L. Maron. 2000. Carbon addition as a countermeasure against biological invasion by plants. Biological Invasions 2:33-40.

Antonsen, H., and P. A. Olsson. 2005. Relative importance of burning, mowing and species translocation in the restoration of a former boreal hayfield: responses of plant diversity and the microbial community. Journal of Applied Ecology 42:337-347. 
Austrheim, G., and O. Eriksson. 2001. Plant species diversity and grazing in the Scandinavian mountains-patterns and processes at different spatial scales. Ecography 24:683-695.

Blumenthal, D. M., N. R. Jordan, and M. P. Russelle. 2003. Soil carbon addition controls weeds and facilitates prairie restoration. Ecological Applications 13:605-615.

Bowman, W. D., J. R. Gartner, K. Holland, and M. Wiedermann. 2006. Nitrogen critical loads for alpine vegetation and terrestrial ecosystem response: are we there yet? Ecological Applications 16:1183-1193.

Corbin, J. D., and C. M. D'Antonio. 2004. Can carbon addition increase competitiveness of native grasses? A case study from California. Restoration Ecology 12:36-43.

Eschen, R., S. R. Mortimer, C. S. Lawson, A. R. Edwards, A. J. Brook, J. M. Igual, K. Hedlund, and U. Schaffner. 2007. Carbon addition alters vegetation composition on ex-arable fields. Journal of Applied Ecology 44:95-104.

Eschen, R., H. Müller-Schärer, and U. Schaffner. 2006. Soil carbon addition affects plant growth in a species-specific way. Journal of Applied Ecology 43:35-42.

Galloway, J. N., and E. B. Cowling. 2002. Reactive nitrogen and the world: 200 years of change. Ambio 31:64-71.

Gough, L., C. W. Osenberg, K. L. Gross, and S. L. Collins. 2000. Fertilization effects on species density and primary productivity in herbaceous plant communities. Oikos 89:428-439.

Hesse, E., M. Rees, and H. Müller-Schärer. 2006. Seed bank persistence of clonal weeds in contrasting habitats: implications for control. Plant Ecology 190:233-243.

Hodge, A., C. D. Campbell, and A. H. Fitter. 2001. An arbuscular mycorrhizal fungus accelerates decomposition and acquires nitrogen directly from organic material. Nature 413:297-299.

Jaeger, C. H. III, R. K. Monson, M. C. Fisk, and S. K. Schmidt. 1999. Seasonal partitioning of nitrogen by plants and soil microorganisms in an alpine ecosystem. Ecology 80:1883-1891.

Kammer, P. M., and A. Möhl. 2002. Factors controlling species richness in alpine plant communities: an assessment of the importance of stress and disturbance. Arctic, Antarctic, and Alpine Research 34:398-407.

Kleijn, D., and H. Müller-Schärer. 2006. The relation between unpalatable species, nutrients and plant species richness in Swiss montane pastures. Biodiversity and Conservation 15:3971-3982.

Kleijn, D., U. Treier, and H. Müller-Schärer. 2005. The importance of nitrogen and carbohydrate storage for plant growth of the alpine herb Veratrum album. New Phytologist 166:565-575.

Körner, C. 2003. Alpine plant life. Springer Verlag, Berlin.

MacDonald, D., J. R. Crabtree, G. Wiesinger, T. Dax, N. Stamou, P. Fleury, J. Gutierrez Lazpita, and A. Gibon. 2000. Agricultural abandonment in mountain areas of Europe: environmental consequences and policy response. Journal of Environmental Management 59:47-69.

McLendon, T., and E. F. Redente. 1992. Effects of nitrogen limitation on species replacement dynamics during early secondary succession on a semiarid sagebrush site. Oecologia 91:312-317.

Michelsen, A., E. Graglia, I. K. Schmidt, S. Jonasson, D. Sleep, and C. Quarmby. 1999. Differential responses of grass and a dwarf shrub to long-term changes in soil microbial biomass $\mathrm{C}, \mathrm{N}$ and $\mathrm{P}$ following factorial addition of NPK fertilizer, fungicide and labile carbon to a heath. New Phytologist 143:523-538.

Nordin, A., I. K. Schmidt, and G. R. Shaver. 2004. Nitrogen uptake by arctic soil microbes and plants in relation to soil nitrogen supply. Ecology 85:955-962.

Oksanen, J. 1990. Predation, herbivory, and plant strategies along gradients of primary production. Pages $445-474$ in J. Grace and D. Tilman, editors. Perspectives on plant competition. Academic Press, New York.

Olsen, S. R., C. V. Cole, F. S. Watanabe, and L. A. Dean. 1954. Estimation of available phosphorus in soils by extraction with sodium bicarbonate. U.S. Dep. of Agric. Circ. 939. U.S. Government Printing Office, Washington, D.C.

Prober, S. M., K. R. Thiele, I. D. Lunt, and T. B. Koen. 2005. Restoring ecological function in temperate grassy woodlands: manipulating soil nutrients, exotic annuals and native perennial grasses through carbon supplements and spring burns. Journal of Applied Ecology 42:1073-1085.

Reever Morghan, K. J., and T. R. Seastedt. 1999. Effects of soil nitrogen reduction on nonnative plants in restored grasslands. Restoration Ecology 7:51-55.

Robson, T. M., S. Lavorel, J.-C. Clement, and X. Le Roux. 2007. Neglect of mowing and manuring leads to slower nitrogen cycling in subalpine grasslands. Soil Biology \& Biochemistry 39:930-941.

Sala, O. E., F. S. Chapin III, J. J. Armesto, E. Berlow, J. Bloomfeld, R. Dirzo, et al. 2000. Global biodiversity scenarios for the year 2100 . Science 287:1770-1774.

Schaffner, U., D. Kleijn, V. Brown, and H. Müller Schärer. 2001. Veratrum album in montane grasslands: a model system for implementing biological control in land management practices for high biodiversity habitats. Biocontrol News and Information 22:19n-28n.

Schimel, J. P., and J. Bennett. 2004. Nitrogen mineralization: challenges of a changing paradigm. Ecology 85:591-602.

Schimel, J. P., and C. Mikan. 2005. Changing microbial substrate use in Arctic tundra soils through a freeze-thaw cycle. Soil Biology \& Biochemistry 37:1411-1418.

Schmidt, I. K., A. Michelsen, and S. Jonasson. 1997a. Effect on plant production after addition of labile carbon to arctic/alpine soils. Oecologia 112:305-313.

Schmidt, I. K., A. Michelsen, and S. Jonasson. 1997b. Effects of labile soil carbon on nutrient partitioning between an arctic graminoid and microbes. Oecologia 112:557-565.

Silvertown, J., P. Poulton, A. E. Johnston, G. Edwards, M. Heard, and P. M. Biss. 2006. The Park Grass Experiment 1856-2006: its contribution to ecology. Journal of Ecology 94:801-814.

Spiegelberger, T. 2006. Land use, soil nutrient availability and conservation of biodiversity on mountain grasslands. Ph.D. thesis. University of Fribourg, Switzerland.

Spiegelberger, T., O. Hegg, D. Matthies, K. Hedlund, and U. Schaffner. 2006a. Long-term effects of short-term perturbation in a sub-alpine grassland. Ecology 87:1939-1944.

Spiegelberger, T., D. Matthies, H. Müller-Schärer, and U. Schaffner. 2006b. Scale-dependent effects of land use on plant species richness of mountain grassland in the European Alps. Ecography 29:541-548.

Suding, K. N., S. L. Collins, L. Gough, C. Clark, E. E. Cleland, K. L. Gross, D. G. Milchunas, and S. Pennings. 2005. Functional- and abundance-based mechanisms explain diversity loss due to $\mathrm{N}$ fertilization. Proceedings of the National Academy of Science of the United States of America 102:4387-4392.

Ter Braak, C. F., and P. Šmilauer. 1999. Canoco for windows. Center for Biometry Wageningen, The Netherlands.

Theodose, T. A., and W. D. Bowman. 1997. Nutrient availability, plant abundance, and species diversity in two alpine tundra communities. Ecology 78:1861-1872.

Török, K., T. Szili-Kovács, M. Halassy, T. Tóth, Z. Hayek, M. W. Paschke, and L. J. Wardell. 2000. Immobilization of soil nitrogen as a possible method for the restoration of sandy grassland. Applied Vegetation Science 3:7-14.

Vitousek, P. M., J. D. Aber, R. W. Howarth, G. E. Likens, P. A. Matson, D. W. Schindler, W. H. Schlesinger, and D. G. Tilman. 1997. Human alteration of the global nitrogen cycle: sources and consequences. Ecological Applications 7:737-750.

Zaller, J. G. 2004. Ecology and non-chemical control of Rumex crispus and R. obtusifolius (Polygonaceae): a review. Weed Research 44: 414-432. 